\title{
Fibroblast Growth Factor 10
}

National Cancer Institute

\section{Source}

National Cancer Institute. Fibroblast Growth Factor 10. NCI Thesaurus. Code C26125.

Fibroblast growth factor 10 (208 aa, $23 \mathrm{kDa}$ ) is encoded by the human FGF10 gene. This protein is involved in embryonic development, morphogenesis, tissue repair, and mitogenesis for keratinizing epidermal cells. 